\title{
FOUR WINDOWS ON BORDERLANDS: DIMENSIONS OF PLACE DEFINED BY LAND COVER CHANGE DATA FROM HISTORICAL MAPS
}

ŠTIRI OKNA OBMEJNEGA OBMOČJA: DIMENZIJE PROSTORA OPREDELJENE S PODATKI O SPREMEMBAH POKROVNOSTI TAL PRIDOBLJENIH IZ ZGODOVINSKIH ZEMLJEVIDOV

Daniela Ribeiro, Julia Ellis Burnet and Gregor Torkar

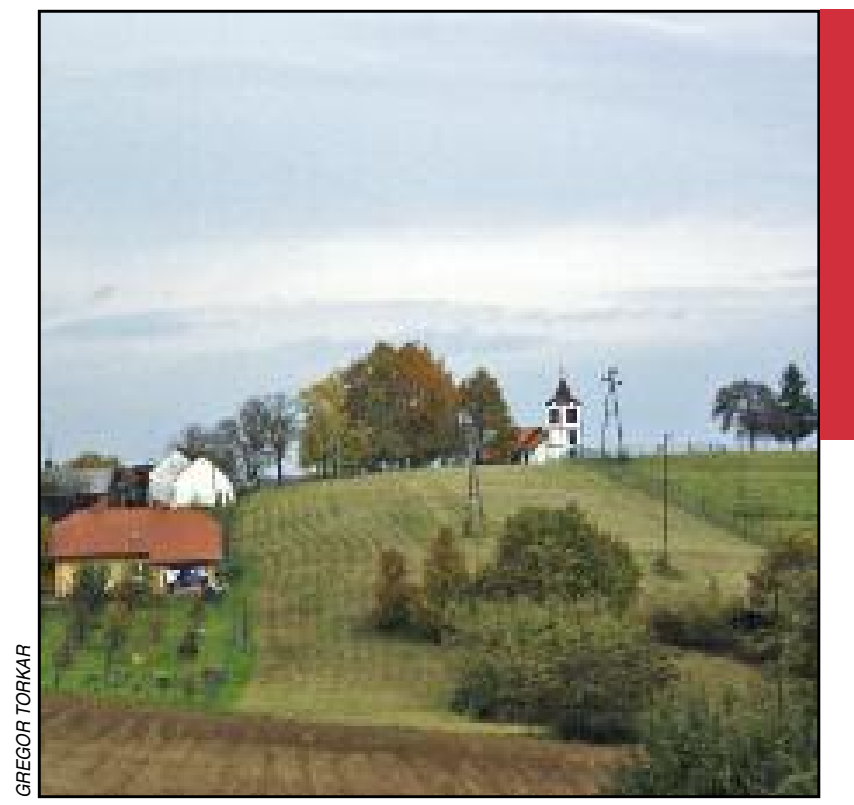

The complexity of small hamlets, fields and beech hangers typical across Goričko. Kompleksen preplet majhnih zaselkov, polj in zaplat gozda je tipičen za Goričko. 


\title{
Four windows on Borderlands: Dimensions of place defined by land cover change data from historical maps
}

\author{
DOI: $10.3986 / A G S 53204$ \\ UDC: $912.43: 711.14(497.411)$ \\ COBISS: 1.01
}

\begin{abstract}
Perceptions of land cover changes from four areas located on the borderlands of Prekmurje, north-eastern Slovenia were determined from a set of historical maps. The principle goals of this research were the calculation of changes in area of land cover categories and analysis of the stability of the study areas from the perspective of land cover. Two approaches were applied to the map analysis: "stability mapping " followed by proportions of different land cover categories determined by time series cartography. Finally, these approaches were triangulated with ground truthing. The results presented demonstrate conclusively that the studied region maintained relatively stability although over several centuries inhabitants withdrew very slightly from both natural boundaries and political borders. As »windows « into the environmental psychology of borderland perception, each small site studied revealed some specifically localised characteristic.
\end{abstract}

KEY WORDS: perception, land cover changes, stability mapping, geographical information system, borderland, Prekmurje, Örség, Central Europe

The article was submitted for publication on February 2, 2012.

\section{ADDRESSES:}

Daniela Ribeiro, Ms. C.

Anton Melik Geographical Institute

Scientific Research Center of the Slovenian Academy of Sciences and Arts

Gosposka ulica 13, SI-1000 Ljubljana, Slovenia

E-mail: daniela.ribeiro@zrc-sazu.si

Julia Ellis Burnet, Ph. D.

Laboratory for Environmental Research

University of Nova Gorica

Vipavska 13, Rožna Dolina, SI-5000 Nova Gorica, Slovenia

E-mail: cactais@gmail.com

\section{Gregor Torkar, Ph. D.}

Laboratory for Environmental Research

University of Nova Gorica

Vipavska 13, Rožna Dolina, SI-5000 Nova Gorica, Slovenia

E-mail: gregor.torkar@ung.si 


\section{Contents}

1 Introduction 320

2 Methodology 320

2.1 Description of study area 320

2.2 Description of cartographic datasets 320

2.3 Methods 321

2.3.1 Approach I 321

2.3.2 Approach II 322

2.3.3 Approach III 322

3 Results 323

4 Discussion 329

4.1 Southeast Goričko 329

4.2 Örség 330

4.3 Mura River floodplain 330

4.4 Southwest Goričko 330

5 Conclusion 330

6 Acknowledgements 331

7 References 331 


\section{Introduction}

Our study builds on concepts expressed by Wrbka et al. (2004) in the understanding of people-place interactions and the definitive attributes of place in Central Europe through long-term landscape use and identity as discussed by Urbanc et al. (2004; 2006), Skokanová (2010), Lettner and Wrbka (2010). Csaplovics (2010) wrote that historic map interpretation is a synthesis of socio-political, economic and cultural attributes both at the time each map was drawn and the understanding of perceptional attributes pertaining to natural and anthropogenic impacts over time which quantify and qualify the map data. Historical maps are frequently the only available source of land cover change; they depict the landscape structure in earlier periods more accurately than alternative sources, thus, they may serve to explain temporal variation in land cover (Cousins 2001; Skokanová et al. 2009). By focusing on landscape meaning over time from an analysis of dynamic socio-economic utilization, population shifts and land cover change a broader understanding of the social process that create, negotiate and assign values can be ascertained.

A goal central to this study was to determine and understand the impacts of natural and political boundaries on land cover patterning over time. Despite of several studies conducted on land cover changes in Slovenia (Gabrovec and Kladnik 1997; Hladnik 2005; Paušič and Čarni 2012; Petek 2002; Urbanc et al. 2004; Urbanc 2008) and changes of traditional cultural landscapes into a novel modern landscape (Razpotnik Visković 2011), this study focused on smaller areas and discusses the impact of political borders on landscape change. In this, the assumption was that land use patterns from the past, for example during the Iron Curtain period, differ from those of today when, due to European accession, borders have lost their purpose of socio- physical division. Olas and Kert (1993) examined how this affected the Prekmurje region through the bordering processes that occurred over the past century and the impact this had on the local economy, property rights, religion and languages used locally. They highlight that these bordering processes led to land abandonment, depopulation and outmigration.

\section{Methodology}

Three different methodological approaches were combined in order to study land cover changes. The first, known as stability mapping was used in order to analyse land cover changes by the trajectory of change. The second method was an analysis of land cover categories through time series that were calculated and compared. Finally, the first two approaches were triangulated with ground truthing where forest land cover was used as an example to verify the analysis of land cover changes in order to validate the results.

\subsection{Description of study area}

Prekmurje is a regional unit located in the uppermost northeast part of Slovenia. To the southwest Prekmurje is demarcated from the rest of Slovenia by the Mura River, on the west and northwest Prekmurje borders with Austria, on the northeast and the east it borders on Hungary and on the southeast it borders on Croatia.

The study area is surrounded by three political borders, each representing its own cultural, political, linguistic and religious traditions, that during different historical periods have contributed to the ambience of the landscape. Four windows on borderland areas were chosen: Southeast Goričko, Örség in Hungary, Mura River floodplain and Southwest Goričko (Figure 1), in order to determine differences in stability in association with natural characteristics from the perspective of natural and imposed boundaries and borders, and also the impact of natural barriers (Ellis Burnet and Ribeiro 2010).

\subsection{Description of cartographic datasets}

Historical maps utilized in this study were produced over approximately 230 years using different cartographical and land surveying techniques. A very important factor pertaining to the quality of maps was their original military purpose. Six maps were studied:

- Joseph II military land survey (1766-1772 and 1782-1785) is also known as the Josephine military map. This dataset, in a scale of $1: 28,800$, shows all the important geographical features in the landscape and is particularly suitable for the detection of land use and cultural landscape changes (Zorn 2007). 


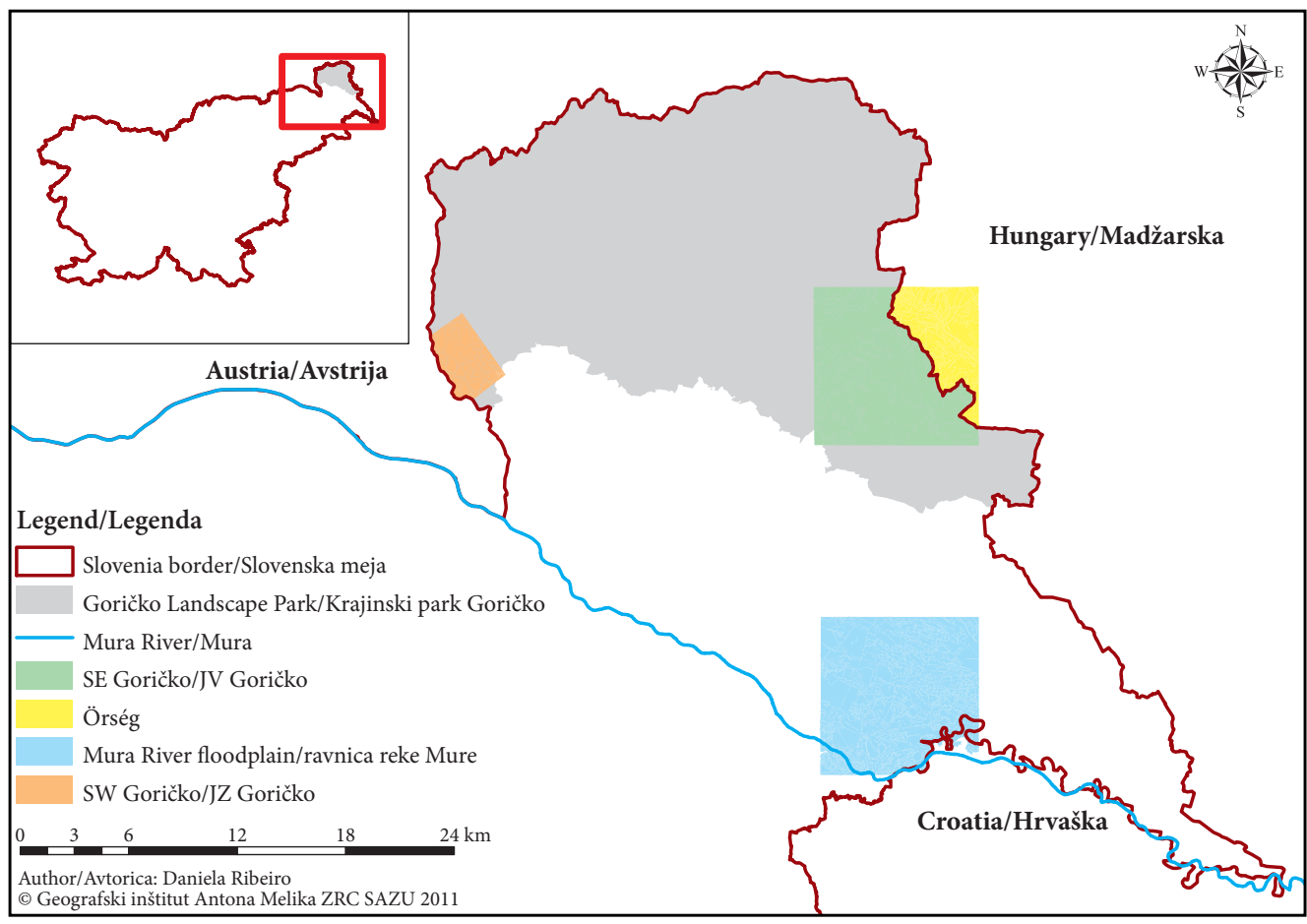

Figure 1: Delimitation of four windows on borderlands of North-eastern Slovenia.

- The second map used known as the Franziscean military map. The Franziscean military map resulted from the Second Military Survey conducted between 1806 and 1869 (Timár 2009). The quality of the data content, cartographic design and aesthetic appearance is outstanding (Timár 2009).

- The third map used corresponds to the military map from the Third Military Survey on a scale of 1:75,000 and it covers large sections of Central Europe and the Balkans. The map sheets were issued after 1880. The accuracy is surprising given the level of technology available at that time although some significant blunders in scale are obvious (Kovas and Timár 2009).

- The forth map used was the topographic map in a scale of $1: 25,000$, produced between $1940-1955$ by the Yugoslavian Military Geographical Institute.

- The fifth map used in this study was produced between 1965-1967 and 1973-1974. After WWII the entire territory of Slovenia was covered by topographic maps in a scale of $1: 25,000$. The mapping was carried out by the Military Geographical Institute of the Yugoslav People's Army (Vojno Geografski Institut Jugoslavije).

- The most recent map available dates from 2009 and was used for three windows (SE Goričko, SW Goričko and Mura River floodplain). For the Örség window the most recent map utilised was the Hungarian Corine Land Cover from year 2006 (Corine ... 2006).

The irregularities incurred by the map maker and the irregularities from vectorization of the land cover layers were not possible to distinguish as the digital processing of the maps, such as georeferencing and vectorizing, were not performed by the authors of this paper, thus these irregularities are reflected in the vector layers used for the analysis.

\subsection{Methods}

\subsubsection{Approach I}

In order to analyse land cover changes by the trajectory of change, a method known as stability mapping was utilised. This process systematically identifies those areas which have been most prone to land cover 
changes and is based on calculation of three indices: similarity, turnover and diversity (Swetnam 2007; Skokanová 2009). Similarity captures information concerning the dominance of any one land cover category at a particular location throughout the time period of available data. Turnover records the number of changes which occurred between adjacent time series. And diversity is the number of different categories recorded for the six time steps (Swetnam 2007).

The cartographic datasets described above were used for the derivation of land cover data, representing periods of 1780s, 1840s, 1880s, 1940s, 1970s, 2006 (for the Örség window) and 2009 (for SE Goričko, SW Goričko and Mura River floodplain). In order to make the data thematically comparable five land cover categories were identified: agriculture, forest, gravel, urban area and inland water. The smallest spatial unit utilized in the analysis was the smallest plot (polygon) with land cover information.

The three indices were then combined in order to derive the change trajectory classes (Swetman 2007): Stable, Quasi-stable, Stepped, Cyclical, Dynamic and No Constant Trend (NCT) (Tables 1 and 2). As the Örség and SW Goričko windows were analysed based only on four time series maps less combinations with the three indices were enabled, therefore, the class NCT did not appear. Polygons with the same level of stability were merged in order to facilitate the visual interpretation. This automated method was developed in the ESRI ArcGIS Desktop 9.3 environment.

Table 1: Combination of similarity, turnover and diversity in order to derive the trajectory classes used on the stability maps when six historical datasets were utilised.

\begin{tabular}{ccclll}
\hline Turnover & Diversity & Similarity & Class & Example & Notes \\
\hline 0 & 1 & 6 & Stable & 111111 & No changes \\
1,2 & 2 & 5 & Quasi-stable & 121111 & Dominant trend with only one change \\
1 & 2 & 3,4 & Stepped & 111222 & One change between two categories \\
$2,3,4,5$ & 2 & $2,3,4$ & Cyclical & 121212 & Frequent change between two categories \\
$3,4,5$ & $3,4,5,6$ & $1,2,3,4$ & Dynamic & 123412 & Frequent change among three categories \\
$2,3,4$ & 3,4 & $2,3,4$ & NCT & 122213 & Variable change of categories several times \\
\hline
\end{tabular}

Table 2: Combination of similarity, turnover and diversity in order to derive the trajectory classes used on the stability maps when four historical datasets were used.

\begin{tabular}{ccccc}
\hline Turnover & Diversity & Similarity & Class & Example \\
\hline 0 & 1 & 4 & Stable & 1111 \\
1,2 & 2 & 3 & Quasi-stable & 1211 \\
1 & 2 & 2 & Stepped & 1122 \\
3 & 2 & 2 & Cyclical & 1212 \\
2 & 3 & 2 & Dynamic & 1123 \\
\hline
\end{tabular}

\subsubsection{Approach II}

In the second approach proportions of different land cover categories over time series were calculated and compared. Land cover areas were extracted from the same historical datasets that were utilised for stability mapping approach. The same land cover categories were used and changes in land cover type proportions through time were presented graphically.

\subsubsection{Approach III}

Ground truthing of forest land cover was used as an essential and intrinsic exercise in order to scientifically validate the information extracted from the map series through stability mapping. Ground observations were used in order to properly interpret existing sources such as the historical maps series that have provide information about land cover changes. A survey of the forest stand condition by placing random modified Whittaker (Ellis Burnet 2004) $10 \mathrm{~m}^{2}$ quadrats in forest stands in Goričko and Örség was applied with observation notes taken across all four areas studied. From this survey the underlying condition of the forest stands were quantitavely ascertained. 


\section{Results}

For each site analysed a stability map was produced together with a graph depicting the change in land cover categories through time.

Stability was the dominant condition across the majority of windows with an average of $59,6 \%$ of area recording no changes through the six time series (four time series for Örség). Considering stable areas as only those with the highest proportion of "Stable« the most stable window is SE Goričko and the least stable is Örség.

Sites with only one change recorded occupy on average $23,5 \%$ of the area of the windows. Nevertheless, if the quasi-stable column is taken into account as a high stability level, as it presents a dominant trend for one category with only one change, the most stable window is SW Goričko followed by SE Goričko, the other study windows were relatively less stable. However, both Mura River floodplain and Örség also present high levels of stability (higher than $70 \%$ of the area).

The stepped change with an average of $12,5 \%$ was the following trajectory of change mapped and for three windows this value was very similar and quite expressive.

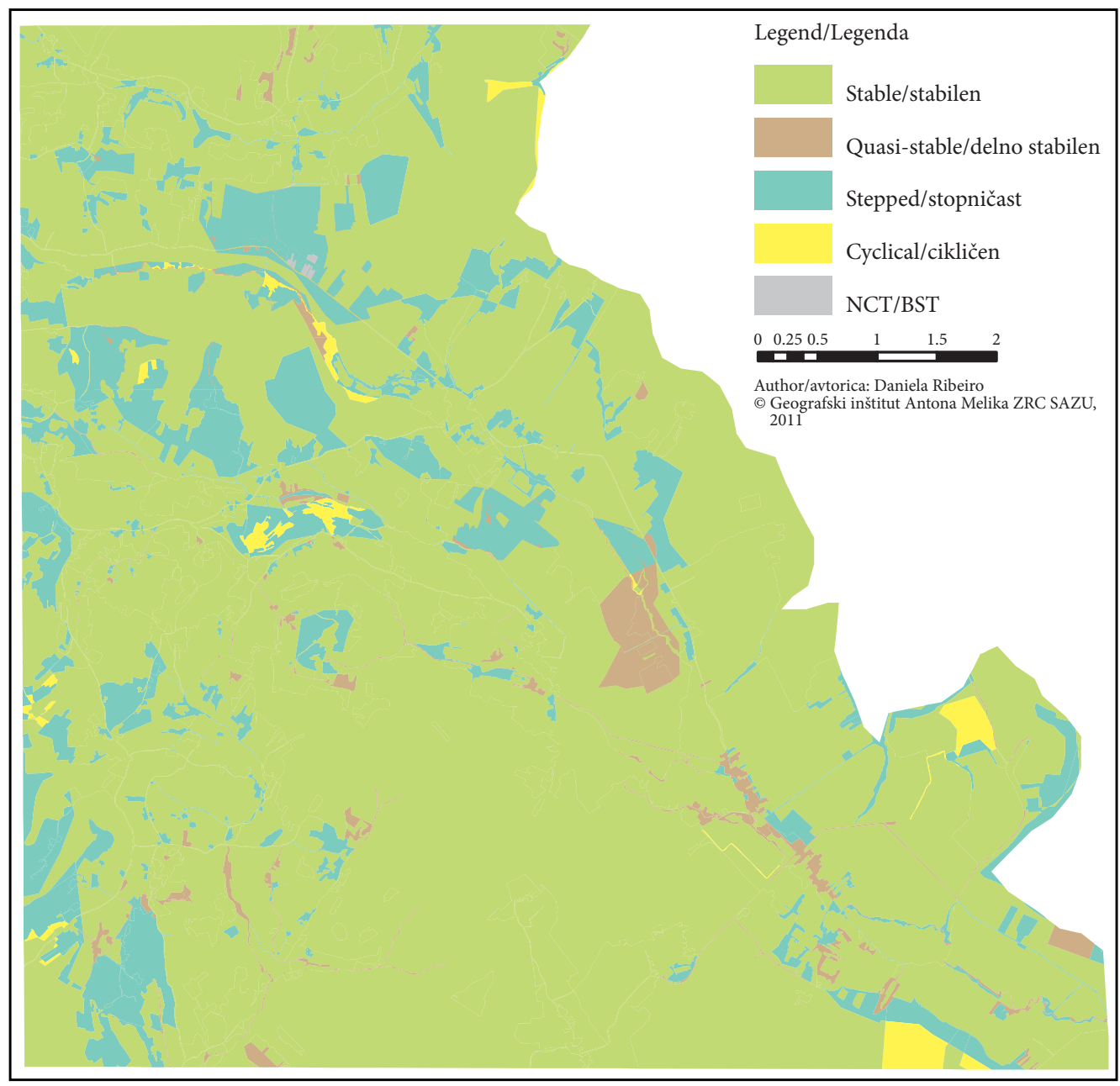

Figure 2: Stability map for Southeast Goričko. 


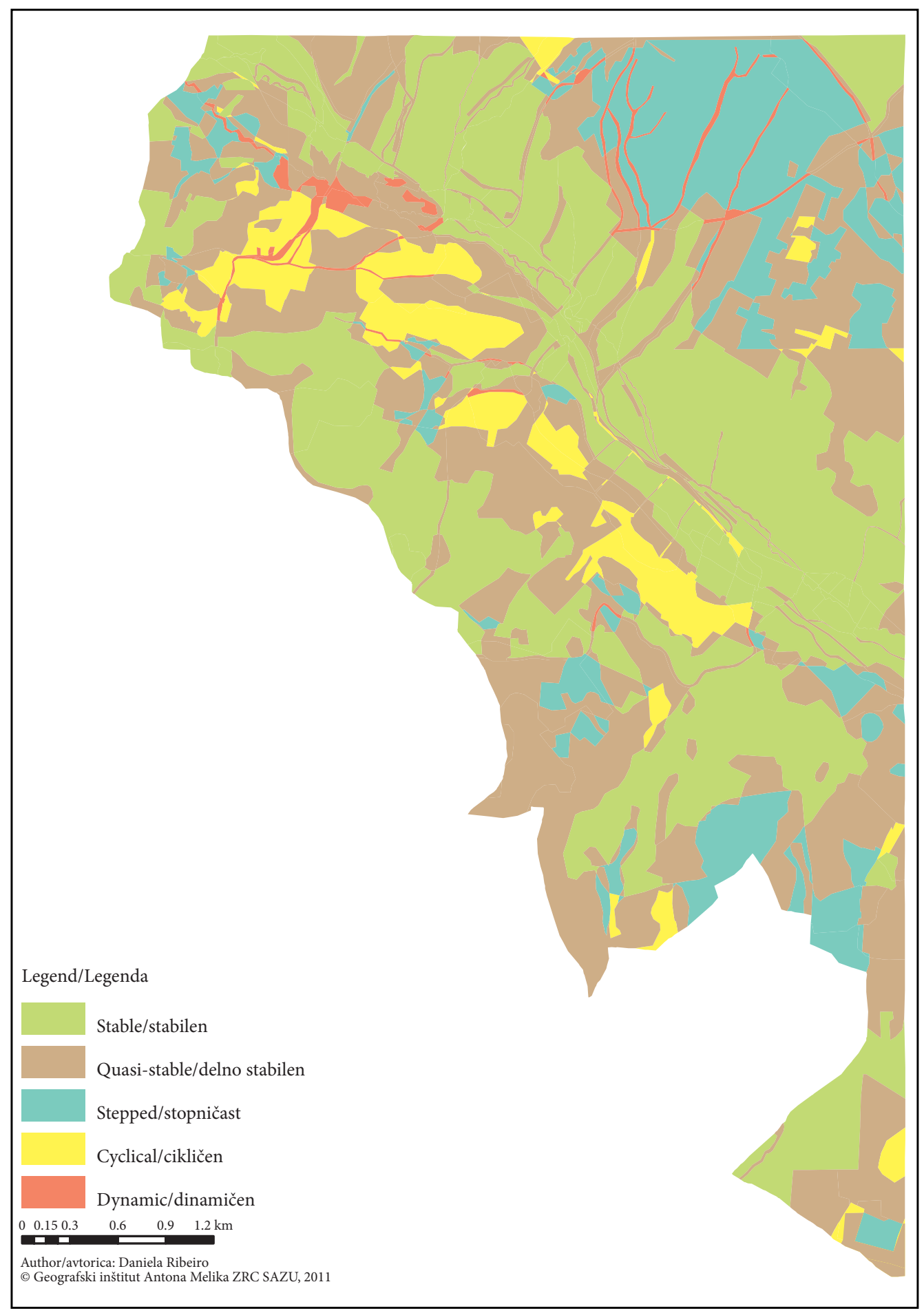

Figure 3: Stability map for Örség. 


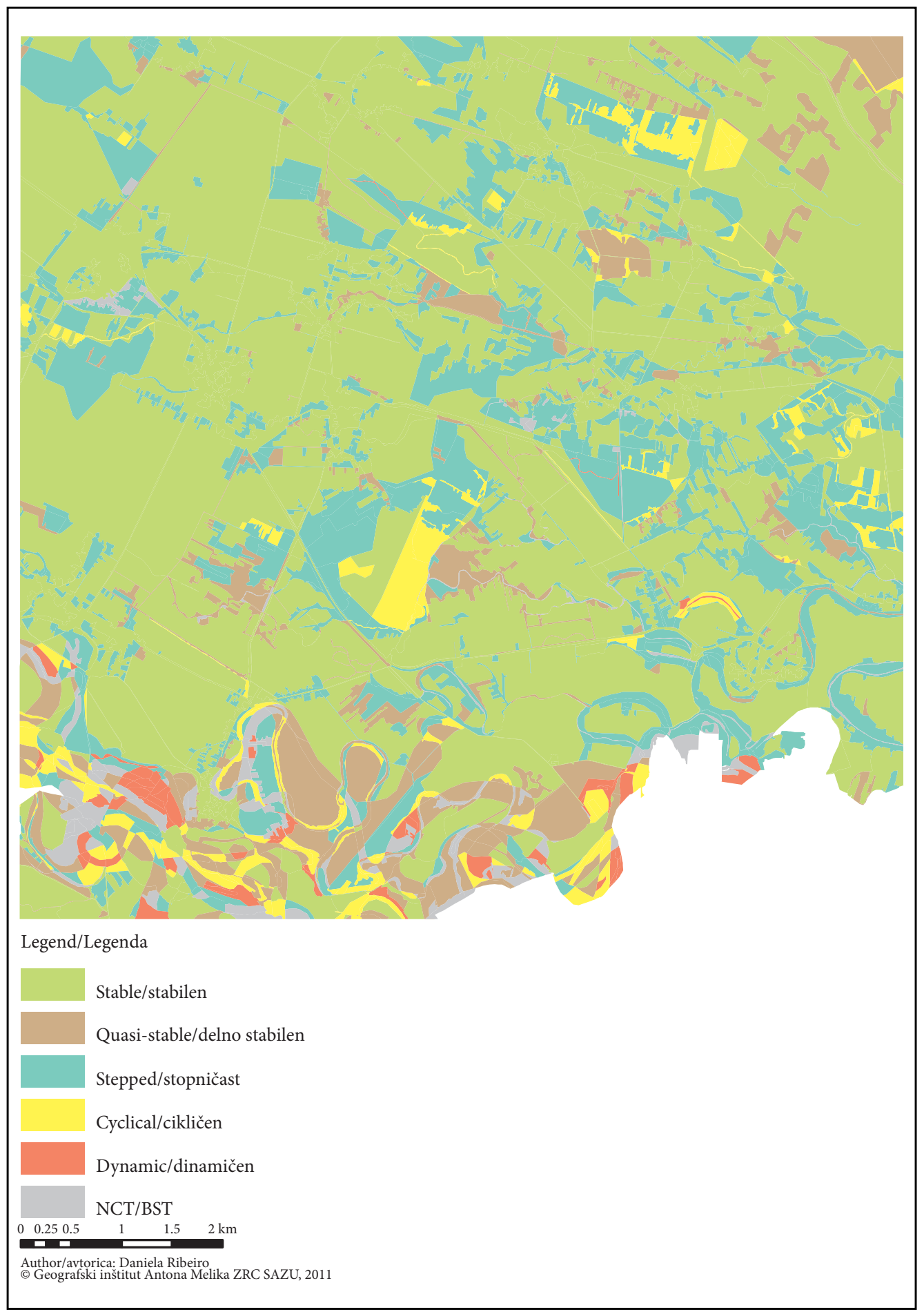

Figure 4: Stability map for Mura River floodplain. 


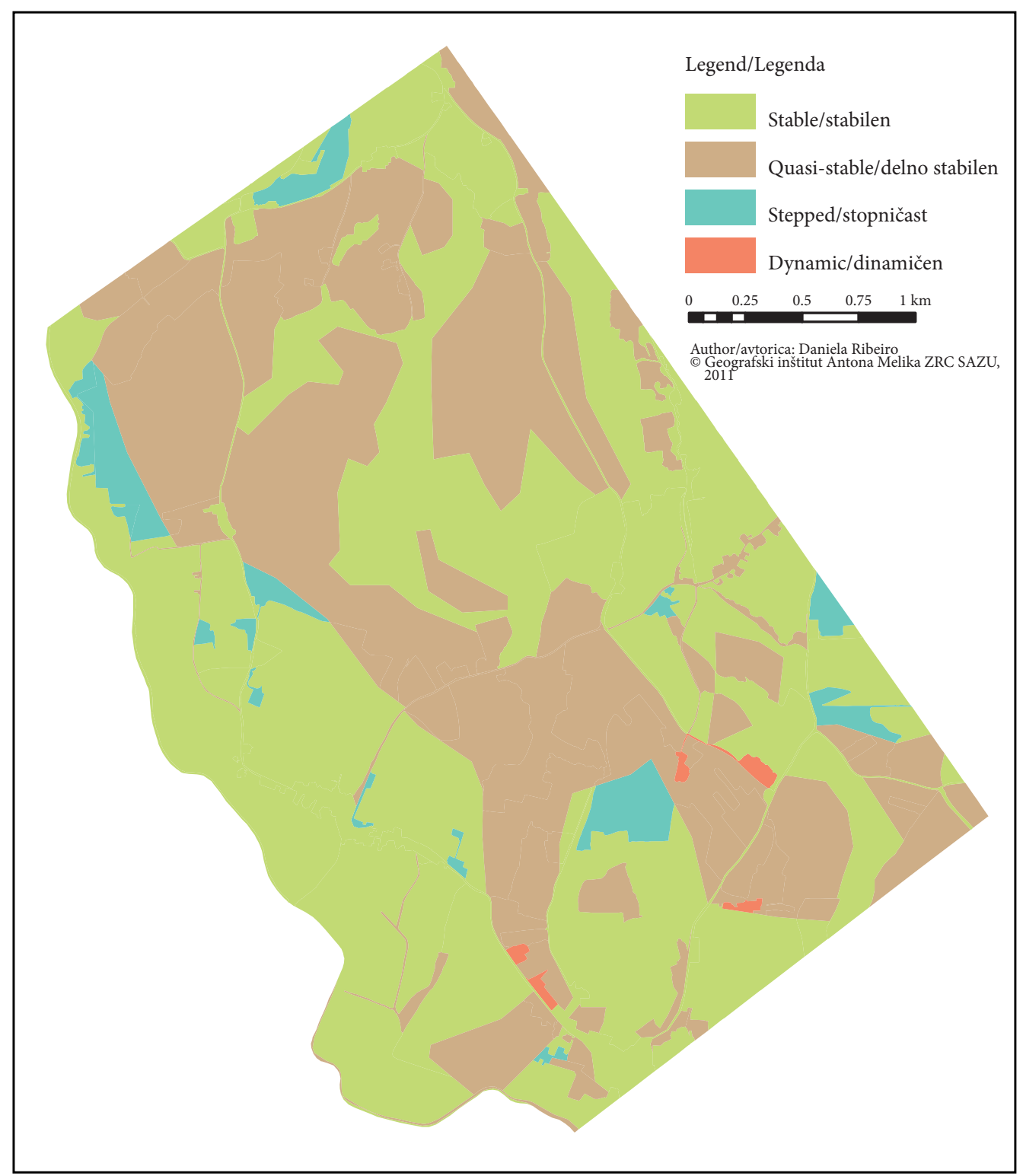

Figure 5: Stability map for Southwest Goričko.

Cyclical change has been identified on average only over $4 \%$ of the area of three study windows. This type of change is probably the most interesting indicator for this method, but it is not well expressed in the results as it wasn't greater than 7\% for the Örség window and lower than this value for the Mura River floodplain and SE Goričko, and not identified at all in SW Goričko. It is important to mention that this process can only be detected if the periodicity (number of maps) allow it.

Although three of the four study areas present dynamic changes the proportion of this column is low in all of the three areas, and was only identified as less than $1 \%$ on average, of the area for these three windows. Thus dynamicity can be defined in overall as very restricted in area. 


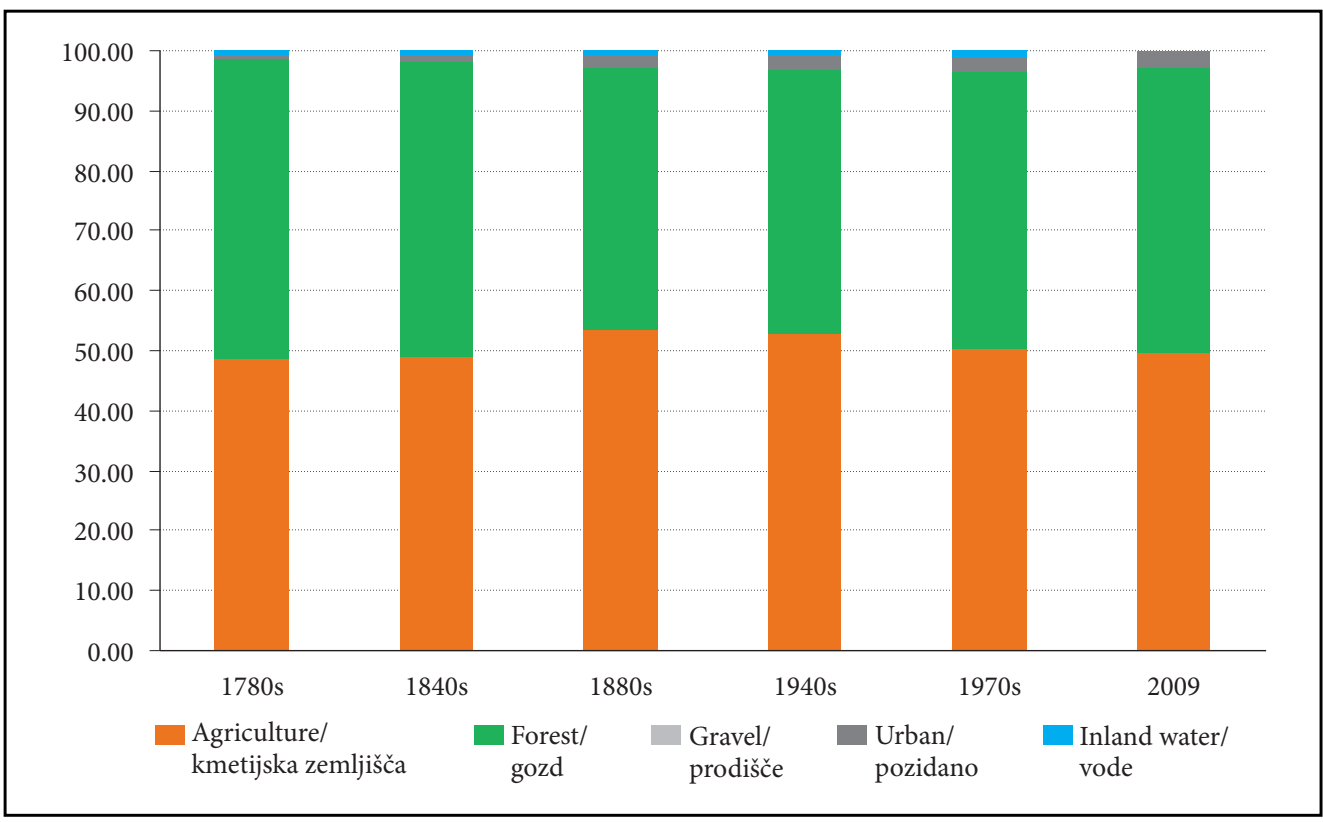

Figure 6: Changes in land cover type proportions through time for Southeast Goričko.

The no clear trend class includes those areas with variable change in categories several times although turnover is not as frequent as in the dynamic areas. NCT can only be identified in two areas and in one of them with a negligible value.

Agricultural areas over the entire map series for the SE Goričko window appear consistent with only minor variations (Figure 6). Forest cover in the 1780s and 1840s was largely consistent but showed significant retraction in 1880s although thereafter again remaining static until the 1940s. Further minor forest retraction occurred in 1970s with consolidation in the central southern area in 2009 with scattered areas of fragmented woodland in the western valley areas. Gravel areas do not occur in any map series for this window. The urban areas increased slightly from the 1780s to 2009. The river systems show an increase in area until the 1970s, after this period the area of inland water was reduced to a negligible value, due in part, to an increase in riparian growth which covered the water surface. The maturity of the forest quadrats examined, the mixed tree composition and regeneration percentage recorded indicates a healthy and dynamic natural system.

The map series shows that agricultural areas in the Örség window slightly increased from the 1780s to 1840s; from 1840s to 2006 these areas decreased by about $10 \%$ from the initial area covered (Figure 7). On the other hand, afforested areas increased in comparable area from the 1780s to 2006. Gravel areas do not occur in this window across the time series studied. The areas occupied by urban fabric and inland water decreased over the time series although these areas are not very evident in this window. The urban area shifted significantly over the map series from a concentration in the south-east to the north-west following the development of a northern road link. This appears to have had a significant demographic impact. Ground truthing of three forest quadrants showed that former orchards and vineyards have been overtaken by encroaching forests.

In the 1780s the agricultural area dominated the studied window for the Mura River floodplain (Figure 8). In the 1840 s most of the agricultural area expanded extending into the riverine corridor and the north eastern forest region. There was a perceptible increase in agricultural land in the 1880s although some land was also lost to urban growth and the shift in the Mura River's channel. The greatest change appears to have occurred in 1940s and was associated with the Mura's riverine corridor with some shifts apparently due to river bed change or modification. Further reduction in agricultural land occurred in the 1970s, 


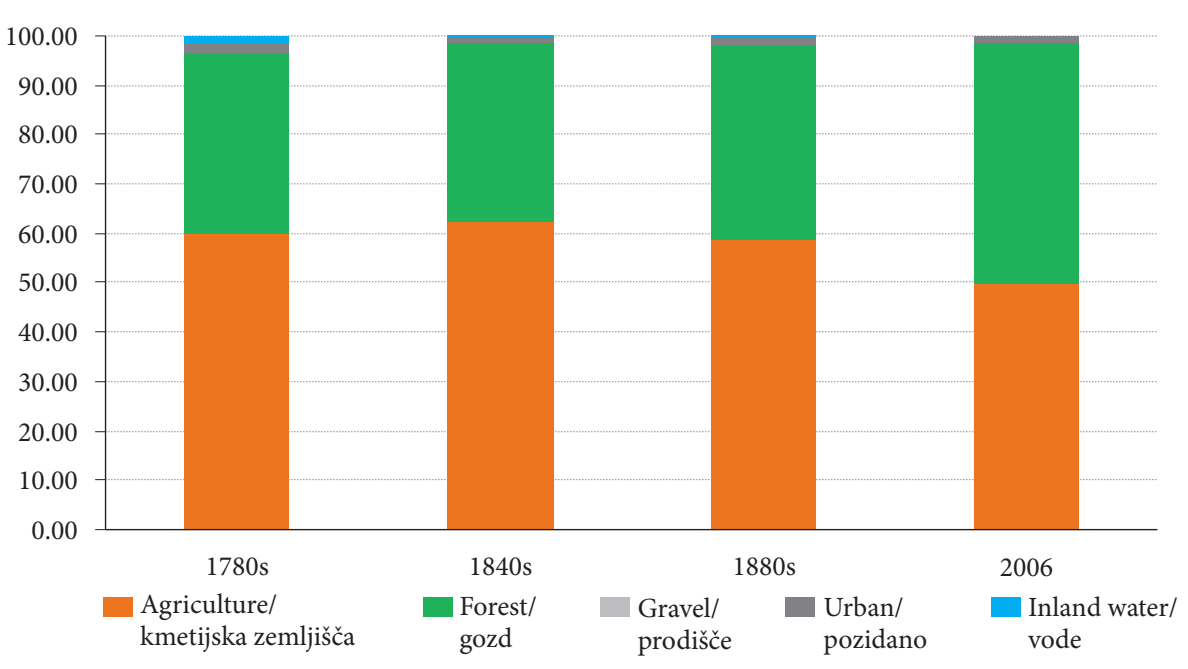

Figure 7: Changes in land cover type proportions through time for Örség.

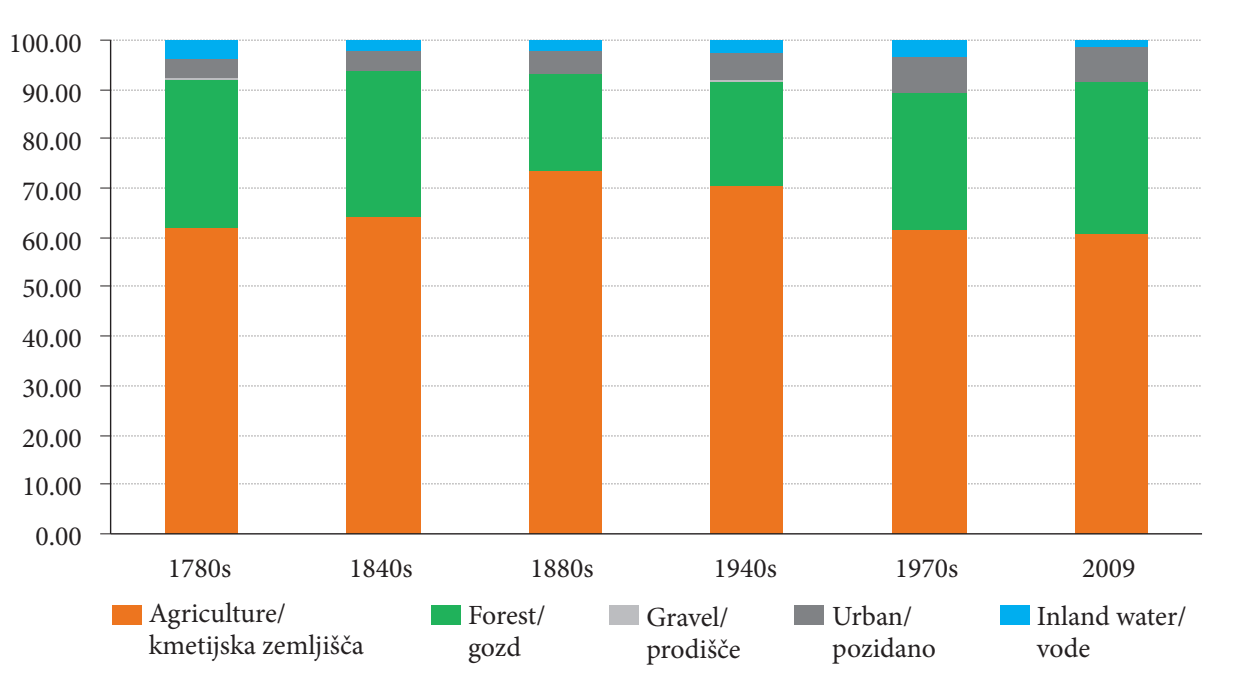

Figure 8: Changes in land cover type proportions through time for the Mura River floodplain.

mostly associated with urban growth but with some small new areas also developed within the riverine corridor. Urban growth and forest expansion were the two principle reasons for agricultural land loss in 2009.

A dramatic loss in forest cover occurred in the 1880s. New woodlands were depicted in 1940s. Substantial forest consolidation occurred in 1970s with the expansion of a new central forest. Afforested land was further consolidated in 2009 with the possible development of roadside avenue plantings.

The total area of gravel benches was oscillatory during the time series, varying with the river dynamics. Urban expansion occurred from the 1780s to 2009. Mura channel changes during the studied time series resulted in straightening and the appearance of new anabranches influencing the area of inland water. 


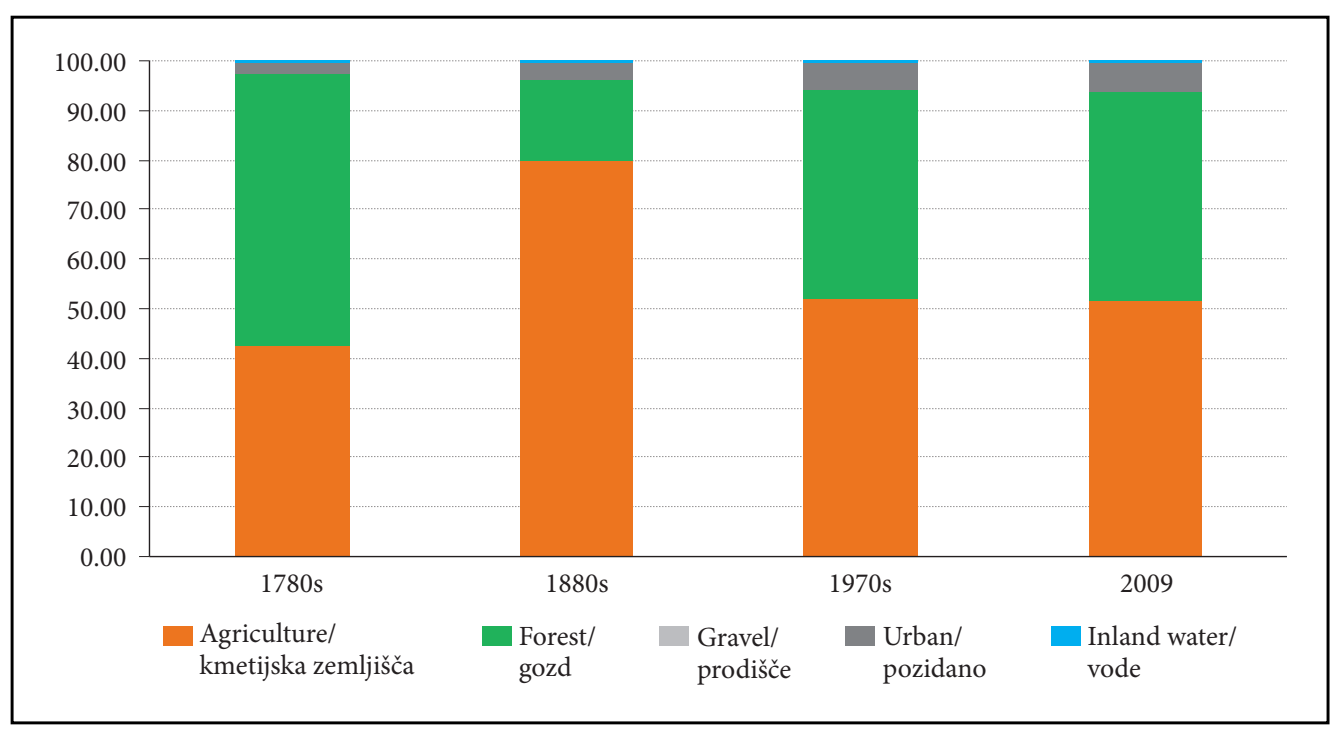

Figure 9: Changes in land cover type proportions through time for Southwest Goričko.

Ground truthing revealed only a limited area of natural riparian vegetation and extensive areas of plantation on the poorly drained fluvial gravels. Soil disturbance through antropogenic activity has facilitated the invasion of alien species that were originally introduced by plantation.

The greatest extent of agricultural coverage that occurred in the 1880 s correlates with the widespread depletion of the forest cover. The later recovery of afforested areas likewise relate to the loss of agricultural land which has continued to regress.

Forests dominated the landscape of this window as shown in the 1780s and although the 1880s map depicts only the south eastern corner of the map area it shows the reduction in forest cover but also the extent of riparian vegetation covering the eastern stream line. In the map from the 1970s massive reafforestation is indicated. Forest corridor effects, possibly associated with road side plantings, appear in the south west in 2009. The remainder of the forest cover depicted in 1970s appears extant. Gravel areas did not occur in this window. There appears a steady growth in road links and urban fabric development over the three Military Maps although the central area of original forest, and later reforested land, remains unpopulated over the entire map series. Urban development increased rapidly from 1970s to 2009. This map window was the only location where the river systems, accurately drawn in 1780s, remained static over time. The only variation occurred in 2009 when riparian vegetation obscured the eastern stream line.

\section{Discussion}

From our analysis important characteristics emerged pertaining to each geographic window and from the interpretation of land cover dynamics derived from the historical map analysis it was possible to demonstrate how boundaries shaped the present landscape of Prekmurje, north-eastern Slovenia.

\subsection{Southeast Goričko}

From the results obtained through the combination of methodologies it was possible to document that southeast Goričko exemplified the concept of landscape aesthetic as »other « than the perceived beauty of some place or vista, thus emphasising the criteria through which the dynamic structure of an environment can be ascertained in a holistic and integrated manner. The stability map illustrates the characteristics of an inherent/aesthetic landscape a distinctive geographic category formulated by Williams and Patterson (1999: 144). 
From the results obtained the consistency in land cover over time reflects the psychological interpretation of Kaplan and Kaplan (1989). This long term stability essentially pertains to a tranquil environment - one of comfort to human inhabitants and acts as a potential criterion for perceived beauty as described by mentioned authors. Ground truthing again confirmed the inherent/aesthetic character of this »window«.

\section{2 Örség}

Political policies have had profound impacts on land cover changes as shown clearly on the stability map (Figure 3) and from groundtruthing results. Family farms were collectivized (Olas and Kert 1993) resulting now in a marked dichotomy in rural affluence between Örség and south-east Goričko, divided by state border.

The »commodity paradigm « has frequently been applied in the past to assess natural resource capacity in promoting behavioural and economic goals (Williams and Patterson 1999). Assumption behind an instrumental view of environmental behaviour closely follow ideas that Saegert and Winkel (1990) identified as the opportunity structure/goal-directed paradigm within environmental psychology. Based on rationality, the instrumental paradigm limited environmental values to those grounded in an economic model (Williams and Patterson 1996). Thus the constraints imposed both on the Örség environment and social structure during the communist era, when commodity production and economic efficiency overruled legitimate emotional associations with place and identity (Williams and Patterson 1996), appears to have tangibly enforced the instrumental/goal directed paradigm.

\subsection{Mura River floodplain}

Screened by its deep riverine corridor and constructed levee bank to limited flooding the Mura still draws attention as a geographical edge, albeit one now channelled and suppressed still significant in defining place and society. For a millennium the Mura River has been both a natural and political division between Prekmurje and the remained of the current Slovenian territory and now acts as a political delineation with the former Yugoslav Republic, nowadays independent country, of Croatia.

In this window the river line dominate the landscape and its activities conferring on it the cultural/symbolic characteristic. Symbolic meaning is generally viewed as more emotionally rich than instrumental meaning as emotion is associated with »being in « the landscape setting.

Although the stability mapping accurately captured the dynamics of river bed change the shift between natural riparian vegetation to recently established plantation stands was not so well depicted. Ground truthing in combination with historical data showed species shift. Species such as Black locust and American ash, were reported as being already planted between 1934 and 1938 in Prekmurje (Potočnik 1939).

\subsection{Southwest Goričko}

The place-identity of southwest Goričko is not only in its modified streams and rich patterning of cultivated fields which have agricultural traditions stretching back to Roman occupation of the region thus the long term stability of this area can be attributed to the soil type and extensive forest bio-resources, which now although in extent similar in size to the forest cover depicted on the Josephine military map, has lost much of its dynamic character due to economic management.

The significance of individual/expressive meanings is captured in the concept of place-identity which arises because places, as bounded locales imbued with personal, social and cultural meanings that provide a significant framework within which identity is constructed, maintained and transformed (Williams 2002; Williams and Patterson 1996; Williams et al. 1992).

\section{Conclusion}

The methodology used in this paper presents a useful approach to analyse land cover dynamics. Stability mapping methodology has been used in several studies on land cover changes and landscape dynamics 
(Skokanová et al. 2009; Swetman 2007). However, they did not establish a connection between land cover changes, people-place interactions and border influences in those changes. The three component indices (similarity, turnover and diversity), relatively simply calculated in GIS, are useful spatial indicators (Swetman 2007). Turnover is the least simple to calculate although it gives the most interesting information about land cover dynamics. The calculation of turnover has a drawback of being subjective interpreted while using only few cartographic datasets. In our study, the calculation of turnover for the Örség and SW Goričko study areas, with only four cartographic datasets available, might result in a subjective interpretation. Thus the number required of input datasets can be a limiting factor. We believe six input datasets is the minimum number in order to allow all processes of change to be detected.

Although the use of historical maps allows analysis of long term changes to a landscape, it is important to mention that this analysis is dependent on the quality of the historical maps and their interpretation. Spatial uncertainties in the historical maps might affect the quality of the historical analysis. The uncertainty of the historical maps used was not measured. For example, in Örség the differences between 1840s and 1880s in the road patterning and the clustering of dwellings could be a result of differences in the accuracy of the maps. Due to their linear characteristic, mapping age and poor trigonometry, there is very little real overlapping of river lines. However, several maps depicted significant landmarks which were included. For example, the very angular bend in the river course above Magyarszombatfa; the angled bridge approach upstream of Velemér and the delineation of the northern tributary associated with a settlement site. Ground truthing was an essential, intrinsic exercise in order to scientifically validate the information extracted from the map series through stability mapping (Ellis Burnet and Ribeiro 2010).

The synthesis of visual map interpretation with stability mapping and subsequent ground truthing (environmental field assessment) of data demonstrates conclusively that the Prekmurje region remained relatively stable over the centuries withdrawing very slightly, but still perceptibly, away from both natural boundaries and borders, such as the Mura River and its history of flooding and channel bed change, to the imposition of politically defined borders of post and electrified fencing, watch towers and heavy military manoeuvring which has also scarred the landscape (Iron curtain). Although the application of the statistical analysis of the map series data was valuable the stability mapping proved definitive in demonstrating conclusively the influence of natural and political boundaries on land cover change.

\section{Acknowledgements}

This paper is an output of the TransEcoNet project implemented through the CENTRAL EUROPE Programme and co-financed by the ERDF. Work was partly done in the framework of the program P4-0107: Forest biology, ecology and technology, which is funded by the Slovenian Research Agency. The authors wish to thank Matija Zorn, Katja Milost, Romina Rodela, Stanka Dešnik and Michael Given for their help and input into this paper. The authors wish to acknowledge the anonymous reviewers for their helpful comments to the previous version of the manuscript.

\section{References}

Corine land cover 2006. European Environment Agency. Copenhagen.

Cousins, S. A. O. 2001: Analysis of land-cover transitions based on 17th and 18th century cadastral maps and aerial photographs. Landscape ecology 16-1. Den Haag.

Csaplovics, E. 2010: Early Regional Maps for Assessment of Landscape History. Workshop on Landscape History. Sopron.

Ellis Burnet, J. 2004: Forest Bioresource Utilisation in the Eastern Mediterranean Since Antiquity: A case study of the Macheras. Oxford.

Ellis Burnet, J., Ribeiro, D. 2010: Land use change in Central Europe: patterns of complexity and transition in a rural landscape. Report UNG-DP-117. University of Nova Gorica. Nova Gorica.

Gabrovec, M., Kladnik, D. 1997: Some New Aspects of Land Use in Slovenia. Acta Geographica 37. Ljubljana.

Hladnik, D. 2005: Spatial structure of disturbed landscapes in Slovenia. Ecological Engineering 24/1-2. Amsterdam. DOI:10.1016/j.ecoleng.2004.12.004 
Kaplan, R., Kaplan, S. 1989: The experience of nature: A psychological perspective. New York.

Lettner, C., Wrbka, T. 2010: Historical Development of the Cultural Landscape at the Northern Border of the Eastern Alps: General Trends and Regional Peculiarities. Workshop on Landscape History. Sopron.

Olas, L., Kert, B. 1993: Vplivi državnih meja na družbenogeografski razvoj Prekmurja. Dela 10. Ljubljana.

Paušič, A., Čarni, A. 2012: Landscape transformationin the low karst plain of Bela krajina (SE Slovenia) over the last 220 years. Acta geographica Slovenica 52-1. Ljubljana. DOI: 10.3986/AGS52102.

Petek, F. 2002: Methodology of Evaluation of Changes in Land Use in Slovenia between 1896 and 1999. Acta Geographica Slovenica 42-1. Ljubljana.

Potočnik, M. 1939: Problemi prekmurskega gozdarstva in nekaj misli o trajnostnem gozdnem gospodarstvu. Odbor za propagando gozdarstva v Murski Soboti. Maribor.

Razpotnik Visković, N. 2011: Spatial limitations on farms in urban outskirts. Acta geographica Slovenica 51-1. Ljubljana. DOI: 10.3986/AGS51105.

Saegert, S., Winkel, G. H. 1990: Environmental psychology. Annual Review of Psychology 41. Kingsport. DOI: 10.1146/annurev.ps.41.020190.002301

Skokanová, H. 2009: Application of methodological principles for assessment of land use change trajectories and processes in South-eastern Moravia for the period 1836-2006. Acta Pruhoniciana 91. Průhonice.

Skokanová, H., Stránská, T., Havlíček, M., Borovec, R., Eremiášová, R., Rysková, R., Svoboda, J. 2009: Land use dynamics of the South Moravian region during last 170 years. GeoScape 1-4. Ústí nad Labem.

Skokanová, H. 2010: Long-term Changes in the Landscape Structure in Three Border Areas of the Czech Republic. Workshop on Landscape History. Sopron.

Swetnam, R. 2007: Rural land use in England and Wales between 1930 and 1988: Mapping trajectories of change with a high resolution spatio-temporal dataset. Landscape and Urban Planning 81/1-2. Amsterdam. DOI: 10.1016/j.landurbplan.2006.10.013.

Timár, G. 2009: System of the 1:28 800 scale sheets of the second military survey in Tyrol and Salzburg. Acta geodaetica et geophysica Hungarica 44-1. Budapest. DOI: 10.1556/AGEOD.44.2009.1.9.

Urbanc, M., Printsmann, A., Palang, H., Skowronek, E., Woloszyn, W., Gyuró, E. K. 2004: Comprehension of rapidly transforming landscapes of Central and Eastern Europe in the 20th century. Acta Geographica Slovenica 44-2. Ljubljana. DOI: 10.3986/AGS44204.

Urbanc, M., Fridl, J., Kladnik, D., Perko, D. 2006: Atlant and Slovene National Consciousness in the Second Half of the $19^{\text {th }}$ Century. Acta geographica Slovenica 46-2. Ljubljana. DOI: 10.3986/AGS46204.

Urbanc, M. 2008: Stories about real and imagined landscapes: the case of Slovenian Istria. Acta geographica Slovenica 48-2. Ljubljana. DOI: 10.3986/AGS48204.

Williams, D. R., Patterson, M.E., Roggenbuck, J. W. 1992: Beyond the Commodity Metaphor: Examining Emotional and Symbolic Attachment to Place. Leisure Sciences 14. Philadelphia.

Williams, D. R., Patterson, M. E. 1996: Environmental Meaning and Ecosystem Management: Perspectives from Environmental Psychology and Human Geography. Society \& Natural Resources 9. New York.

Williams, D. R., Patterson, M. E. 1999: Environmental Psychology: Mapping landscape meanings for ecosystem management. Cordell, H. K., Bergstrom, J. C. (eds.) Integrating social sciences and ecosystem management: Human dimensions in assessment, policy and management. Champaign.

Williams, D. R. 2002: Social construction of arctic wilderness: place meanings, value pluralism, and globalization. Watson, A. E., Alessa, L., Sproull, J. (eds.) Wilderness in the Circumpolar North: searching for compatibility in ecological, traditional, and ecotourism values. Proceedings RMRS-P-26. Alaska.

Wrbka, T., Erb, K., Schulz, N. B., Peterseil, J., Hahn, C., Haberl, H. 2004: Linking pattern and process in cultural landscapes. An empirical study based on spatially explicit indicators. Land Use Policy 21-3. Amsterdam. http://dx.doi.org/10.1016/j.landusepol.2003.10.012.

Zorn, M. 2007: Jožefinski vojaški zemljevid kot geografski vir. Geografski vestnik 79-2. Ljubljana. 



\section{Štiri okna obmejnega območja: dimenzije prostora opredeljene s podatki o spremembah pokrovnosti tal pridobljenih iz zgodovinskih zemljevidov}

DOI: $10.3986 / A G S 53204$

UDK: 912.43:711.14(497.411)

COBISS: 1.01

IZVLEČEK: S pomočjo niza zgodovinskih zemljevidov smo analizirali percepcijo sprememb pokrovnosti tal v štirih oknih, ki ležijo v obmejnih področjih Prekmurja v severovzhodni Sloveniji. Glavna cilja raziskave sta bila izračunati spremembe v kategorijah pokrovnosti tal in analiza stabilnosti raziskovanih oken obmejnega področja z vidika pokrovnosti tal. Uporabili smo dva načina analize zemljevidov: najprej smo izvedli kartiranje stabilnosti, z namenom oblikovati razrede spreminjanja kategorij pokrovnosti tal; sledil je izračun in primerjava deležev različnih kategorij pokrovnosti tal skozi časovna obdobja.

Rezultati jasno kažejo, da so so preučevana območja v regiji ostala relativno stabilna. Skozi stoletja se je prebivalstvo počasi odmikalo stran od naravnih in političnih meja. Kot »okna« v okoljsko psihologijo konceptov obmejnosti je vsako preučevano področje odkrilo lokalne značilnosti.

KLJUČNE BESEDE: dojemanje, spremembe pokrovnosti tal, kartiranje stabilnosti, geografski informacijski sistem, obmejno območje, Örség, Prekmurje, Srednja Evropa

Uredništvo je prejelo prispevek 2. februarja 2012.

NASLOVI:

mag. Daniela Ribeiro

Geografski inštitut Antona Melika

Znanstvenoraziskovalni center Slovenske akademije znanosti in umetnosti

Gosposka ulica 13, SI - 1000 Ljubljana, Slovenija

E-pošta: daniela.ribeiro@zrc-sazu.si

\section{dr. Julia Ellis Burnet}

Univerza v Novi Gorici

Vipavska ulica 13, Rožna Dolina, SI - 5000 Nova Gorica

E-pošta: cactais@gmail.com

\section{Gregor Torkar, Ph. D.}

Laboratorij za okoljske raziskave

Univerza v Novi Gorici

Vipavska ulica 13, Rožna Dolina, SI - 5000 Nova Gorica

E-pošta: gregor.torkar@ung.si 


\section{Vsebina}

1 Uvod 336

2 Metodologija 336

$2.1 \quad$ Opis preučevanega območja 336

2.2 Opis kartografskih podatkovnih baz 336

2.3 Metode 337

2.3.1 Pristop I 337

2.3.2 Pristop II 338

2.3.3 Pristop III 338

3 Rezultati 338

4 Razprava 340

4.1 Jugovzhodno Goričko 340

4.2 Örség 340

4.3 Poplavna ravnica reke Mure 341

4.4 Jugozahodno Goričko 341

5 Sklep 341

6 Zahvala 342

7 Literatura 342 


\section{Uvod}

Naša študija idejno temelji na konceptih Wrbke in sodelavcev (2004) o razumevanju součinkovanja družbe in prostora ter na atributih, ki so pripisani nekemu prostoru z dolgotrajno uporabo pokrajine in identiteto, ki ji je pripisana. V Srednji Evropi so o tem razpravljali tudi Urbanc in sodelavci $(2004 ; 2006)$, Skokanová (2010) ter Lettner in Wrbka (2010). Csaplovics (2010) je ugotovil, da naše interpretacije zgodovinskih zemljevidov temeljijo predvsem na družbeno-političnih, gospodarskih in kulturnih razmerah, ki so prevladovale ob nastanku zemljevida ter na takratnem razumevanju naravnih in antropogenih vplivov skozi čas, ki so količinsko določili in kvalificirali podatke na zemljevidu. Ker so zgodovinski zemljevidi pogosto edini razpoložljiv vir za preučevanje sprememb pokrovnosti tal (bolj podrobno prikazujejo preteklo podobo pokrajine), lahko pomagajo razložiti časovno odstopanje v pokrovnosti tal (Cousins 2001; Skokanová in sodelavci 2009). Če preučujemo pomen pokrajine skozi čas z analizo sprememb njene družbeno-gospodarske rabe, sprememb števila prebivalstva in sprememb pokrovnosti tal, lahko bolje razumemo družbene procese, ki ustvarjajo, pogojujejo in določajo naše vrednote.

Poglavitni cilj raziskave je bil določiti in razumeti učinke naravnih in političnih meja na vzorce pokrovnosti tal skozi čas. Za razliko od številnih raziskav, ki so bile izpeljane na temo sprememb pokrovnosti tal v Sloveniji (Gabrovec in Kladnik 1997; Hladnik 2005; Paušič and Čarni 2012; Petek 2002; Urbanc in sodelavci 2004; Urbanc 2008) ter spreminjanja kulturne pokrajine v sodobno pokrajino (Razpotnik Visković 2011), se ta raziskava osredotoča na manjša območja in predvsem na vpliv političnih meja na spremembe v pokrajini. Postavili smo tezo, da se načini rabe tal iz preteklosti, na primer iz časov Železne zavese, razlikujejo od današnjih. Olas in Kert (1994) sta preučila, kako so spremembe državnih mej v prejšnjem stoletju vplivale na Prekmurje, in kakšen učinek so imele na krajevno gospodarstvo, lastninske pravice, vero in narečja. Ugotavljata, da je postavljanje mej povzročilo opuščanje rabe tal in zmanjševanje števila prebivalcev, predvsem zaradi izseljevanja. Potem ko se je Slovenija priključila Evropski uniji, so meje izgubile svoj prvotni namen družbeno-fizične delitve.

\section{Metodologija}

Spremembe pokrovnosti tal smo preučili s tremi metodološkimi pristopi. Prvega imenujemo kartiranje stabilnosti in smo ga uporabili za analizo sprememb pokrovnosti tal. Z drugo metodo smo izračunali in primerjali kategorije pokrovnosti tal $\mathrm{v}$ časovnem zaporedju. Na koncu smo rezultate preverili s terenskim delom. Gozdno pokrovnost tal smo uporabili kot merilo, s katerim smo preverili analizo sprememb pokrovnosti tal in tako potrdili rezultate.

\subsection{Opis preučevanega območja}

Prekmurje je regija na skrajnem severovzhodu Slovenije, ki ga obkrožajo tri državne meje. Za vsako leži drugačna kulturna, politična, jezikovna in verska tradicija, ki je skozi zgodovino prispevala k videzu pokrajine. Za analizo smo izbrali štiri okna obmejnega območja: jugovzhodno Goričko, Örség na Madžarskem, poplavna ravnica reke Mure in jugozahodno Goričko (slika 1). Na izbranih področjih želimo analizirati spremembe v stabilnosti in njihovo povezavo z naravnimi značilnostmi v smislu naravnih in umetnih mej, kot tudi učinka naravnih mej (Ellis Burnet in Ribeiro 2010).

Slika 1: Razmejitev štirih oken na obmejnih območjih v severovzhodni Sloveniji.

Glej angleški del prispevka.

\subsection{Opis kartografskih podatkovnih baz}

Zgodovinski zemljevidi, ki smo jih uporabili v tej raziskavi, so nastali v obdobju 230 let $\mathrm{z}$ uporabo različnih kartografskih in geodetskih metod. Najpomembnejši dejavnik, ki je prispeval h kakovosti zemljevidov, je dejstvo, da so bili namenjeni vojaške uporabi. Preučili smo šest zemljevidov: 
- Jožefinski vojaški zemljevid (1766-1772 in 1782-1785). Ta podatkovna baza je v merilu $1: 28.800$ in prikazuje vse pomembne geografske prvine v pokrajini. Primerna je predvsem za preučevanje rabe tal in sprememb kulturne pokrajine (Zorn 2007).

- Drugi zemljevid je znan kot Franciskejski vojaški zemljevid. Na podlagi druge vojaške izmere, ki je bila izdelana med letoma 1806 in 1869 (Timár 2009). Kakovost vsebovanih podatkov, kartografska oblika in estetski videz so nadpovprečni (Timár 2009).

- Tretji zemljevid ustreza vojaškemu zemljevidu tretje izmere. Je v merilu 1:75.000 in pokriva velika območja Srednje Evrope in Balkana. Zemljevidi so bili izdani po letu 1880. Natančnost je presenetljivo dobra glede na obstoječo tehnologijo $\mathrm{v}$ tistem obdobju, čeprav so nekatere napake $\mathrm{v}$ merilu precej očitne (Kovas in Timár 2009).

- Četrti zemljevid je topografski zemljevid v merilu 1:25,000, ki je nastal med 1940 in 1955 na Vojno-geografskem inštitutu v Beogradu.

- Peti preučevani zemljevid je nastajal med letoma 1965 in 1967 ter med letoma 1973 in 1974. Po drugi svetovni vojni je bilo celotno slovensko ozemlje kartirano z zemljevidi v merilu $1: 25.000$. Kartiranje je opravil Vojno Geografski Institut Jugoslavije.

- Za tri okna (jugovzhodno Goričko, jugozahodno Goričko in poplavno ravnico reke Mure) so bili uporabljeni najnovejši zemljevidi iz leta 2009. Za okno Örség je bil uporabljen madžarski zemljevid po Corine land cover klasifikacijskem ključu iz leta 2006 (Corine ... 2006).

Med digitalnim procesiranjem zemljevidov ni bilo mogoče razlikovati nepravilnosti avtorja zemljevida in nepravilnostmi zaradi vektorizacije slojev pokrovnosti tal, saj avtorji raziskave niso opravili georeferenciranja in vektorizacije; tako se omenjene nepravilnosti pojavljajo v vektorskih slojih, ki so bili analizirani.

\subsection{Metode}

\subsubsection{Pristop I}

Za analizo sprememb pokrovnosti tal smo uporabili metodo kartiranja stabilnosti. Z njo smo sistematično identificirali območja, ki so bila najbolj podvržena spremembam pokrovnosti tal. Metoda temelji na izračunu treh kazalcev: podobnosti, preobrata in raznolikosti (Swetnam 2007; Skokanová 2009). Podobnost obsega podatke o prevladi katere koli od kategorij pokrovnosti tal na določeni lokaciji skozi čas. Preobrat beleži število sprememb, ki so se zgodile med sosednjimi časovnimi zaporedji. Raznolikost pa pomeni število različnih kategorij, ki so bile izmerjene v šestih časovnih korakih (Swetnam 2007).

Iz opisanih kartografskih podatkovnih baz smo izluščili podatke o pokrovnosti tal, ki predstavljajo obdobja 1780-ih, 1840-ih, 1880-ih, 1940-ih, 1970-ih, 2006 (za okno Örség) in 2009 (za okna jugovzhodno Goričko, jugozahodno Goričko in poplavno ravnico reke Mure). Določili smo pet kategorij pokrovnosti tal: poljedelstvo, gozd, prodišče, pozidano območje in celinske vode.

Najmanjša prostorska enota, ki smo jo uporabili na začetku, je najmanjša parcela (večkotnik), ki vsebuje podatke o pokrovnosti tal.

Tri kazalce smo združili in tako poti spreminjanja razvrstili v naslednje razrede (Swetnam 2007): stabilen, delno-stabilen, stopničast, cikličen, dinamičen in pot spreminjanja brez stalnega trenda (BST) (preglednica 1 in 2). Okni Örség in severozahodno Goričko smo analizirali s pomočjo samo štirih časovnih zaporedij zgodovinskih zemljevidov, zato smo uporabili le tri kazalce brez razreda »Brez stalnega trenda «. Območja $\mathrm{z}$ enako ravnijo stabilnosti smo združili in jih prikazali na zemljevidu.

Metodo smo avtomatizirali in razvili v okolju ESRI ArcGIS Desktop 9.3.

Preglednica 1: Združevanje podobnosti, preobrata in raznolikosti za izračun razredov poti spreminjanja, ki smo jih uporabili pri kartiranju stabilnosti, če je bilo na voljo šest zgodovinskih podatkovnih baz.

\begin{tabular}{ccclll}
\hline preobrat & raznolikost & podobnost & razred & primer & opombe \\
\hline 0 & 1 & 6 & stabilen & 111111 & ni sprememb \\
1,2 & 2 & 5 & delno-stabilen & 121111 & dominanten trend s samo eno spremembo \\
1 & 2 & 3,4 & stopničast & 111222 & ena sprememba med dvema kategorijama \\
$2,3,4,5$ & 2 & $2,3,4$ & cikličen & 121212 & pogoste spremembe med dvema kategorijama \\
$3,4,5$ & $3,4,5,6$ & $1,2,3,4$ & dinamičen & 123412 & pogoste spremembe med tremi kategorijami \\
$2,3,4$ & 3,4 & $2,3,4$ & brez stalnega trenda & 122213 & spremenljive in pogoste spremembe kategorij \\
\hline
\end{tabular}


Daniela Ribeiro, Julia Ellis Burnet, Gregor Torkar, Štiri okna obmejnega območja: dimenzije prostora opredeljene s podatki ...

Preglednica 2: Združevanje podobnosti, preobrata in raznolikosti za izračun razredov poti spreminjanja, ki smo jih uporabili pri kartiranju stabilnosti, če so bile na voljo štiri zgodovinske podatkovne baze.

\begin{tabular}{ccccc}
\hline preobrat & raznolikost & podobnost & razred & primer \\
\hline 0 & 1 & 4 & stabilen & 1111 \\
1,2 & 2 & 3 & delno-stabilen & 1211 \\
1 & 2 & 2 & stopničast & 1122 \\
3 & 2 & 2 & cikličen & 1212 \\
2 & 3 & 2 & dinamičen & 1123 \\
\hline
\end{tabular}

\subsubsection{Pristop II}

Pri drugi uporabljeni metodi smo izračunali in primerjali deleže različnih kategorij rabe tal v časovnem zaporedju. Podatke o rabi tal smo pridobili iz istih zgodovinskih podatkovnih baz, ki smo jih uporabili za kartiranje stabilnosti. Kategorije rabe tal in razmerja kategorij med rabami tal skozi čas smo grafično prikazali.

\subsubsection{Pristop III}

Preverjanje rabe tal v gozdu je bilo ključnega pomena, da smo lahko znanstveno potrdili podatke, ki smo jih pridobili iz serije zemljevidov s kartiranjem stabilnosti. Ugotovitve s terena so nam pomagale, da smo lahko pravilno interpretirali obstoječe naravne vire ter serije zgodovinskih zemljevidov, ki so vsebovali podatke o spremembah pokrovnosti tal. Stanje gozdnega sestoja smo raziskali s pomočjo naključnih modificiranih Whittakerjevih kvadrantov velikosti $10 \mathrm{~m}^{2}$ (Ellis Burnet 2004). S pomočjo zbranih podatkov na štirih preučevanih območjih, smo določili splošno stanje gozdnega sestoja.

\section{Rezultati}

Za vsako analizirano območje smo izdelali zemljevid stabilnosti skupaj z grafom, ki prikazuje spremembe v rabi tal skozi čas. Prevladujoče stanje v večini oken je stabilno, s povprečno površino 59,6\% območja. $\mathrm{Na}$ teh območjih v šestih časovnih zaporedjih ni bilo sprememb (štiri časovna zaporedja za Örség). Če upoštevamo, da so stabilna območja le tista, ki imajo največji delež v stolpcu stabilna, je najbolj stabilno okno jugovzhodno Goričko in najmanj stabilno okno Örség.

Območja, kjer je bila v obravnavanem časovnem obdobju le ena sprememba, v povprečju obsegajo 23,5\% površine oken. Če upoštevamo tudi delno-stabilna območja oken skupaj s stabilnimi območji lahko ugotovimo, da je najbolj stabilno okno jugozahodno Goričko, ki mu sledi jugovzhodno Goričko, ostali dve preučevani okni pa sta manj stabilni (poplavna ravnica reke Mure in Örség). Slednji kljub temu izkazujeta visoko stopnjo stabilnosti (več kot $70 \%$ območja).

Stopničasta sprememba s povprečno površino $12,5 \%$, je bila naslednja kartirana pot spreminjanja. Ta je bila zelo podobna in precej izrazita v vseh treh analiziranih oknih.

Ciklične spremembe smo zabeležili v povprečju samo na $4 \%$ površine treh preučevanih oken. Tovrstne spremembe $\mathrm{v}$ površinah so verjetno najbolj zanimiv indikator metode, a ne izstopa v rezultatih; stopničaste spremembe so bile največje (7\%) v oknu Örség in podpovprečne v oknu poplavne ravnice reke Mure in oknu jugvzhodno Goričko. V oknu jugozahodno Goričko pa so bile stopničaste spremembe nezaznavne. Pomembno je tudi omeniti, da je stopničaste spremembe mogoče zaznati le, če je na voljo dovolj zgodovinskih zemljevidov.

Čeprav tri od štirih preučevanih oken izkazujejo dinamične spremembe, je delež površin majhen. V vseh treh oknih so dinamične spremembe povprečno obsegale manj kot $1 \%$ območja. Tako lahko govorimo o dinamičnosti le na zelo omejenem območju.

Stolpec Brez stalnega trenda vključuje območja z variabilno spremenljivostjo, čeprav preobrat ni tako pogost kot je v dinamičnih območjih. Območja brez stalnega trenda smo določili le na dveh območjih in $\mathrm{v}$ enem od teh le z zanemarljivo vrednostjo.

Glej angleški del prispevka. 
Slika 3: Karta stabilnosti za Örség.

Glej angleški del prispevka.

Slika 4: Karta stabilnosti za poplavno ravnico reke Mure.

Glej angleški del prispevka.

Slika 5: Karta stabilnosti za jugozahodno Goričko.

Glej angleški del prispevka.

Slika 6: Spremembe v razmerjih tipov pokrovnosti tal skozi čas za jugovzhodno Goričko.

Glej angleški del prispevka.

Poljedelska območja so v celotni seriji zemljevidov za jugovzhodno Goričko konsistentna z le redkimi variacijami (slika 2). V 1780-ih in 1840-ih je bila gozdna pokrovnost v veliki meri konsistentna, nato pa se je v 1880-ih pokazalo precejšnje zmanjšanje. Stanje je ostalo večinoma nespremenjeno do 1940-ih. V sedemdeseti letih 20. stoletja je prišlo še do manjšega krčenja površine gozda. Leta 2009 je prišlo do zgostitve gozda v osrednjem južnem delu ter do razdrobitve gozdnih območij na zahodnem dolinskem delu. Na nobeni od serij zemljevidov obravnavanega okna ni bilo mogoče zaslediti prodišč. Pozidana območja so se v obdobju od 1780-ih do 2009 nekoliko povečala. Rečni sistem kaže rahlo povečanje do 1970-ih. Po tem obdobju pa se je območje celinskih voda zmanjšalo, verjetno predvsem zaradi povečanja obrežnega gozda, ki je zakril vodno površino. Zrelost gozdnih kvadrantov, ki smo jih preučili, mešana sestava dreves in stopnja regeneracije kažejo na zdrav in dinamičen naravni sistem.

Slika 7: Spremembe v razmerjih tipov pokrovnosti tal skozi čas za Örség.

Glej angleški del prispevka.

Poljedelska območja v oknu Örség so se nekoliko povečala med 1780-imi in 1840-imi; od 1840-ih do leta 2006 so se ta območja ponovno skrčila za približno desetino (slika 3). Predvsem v obdobju od 1780-ih do leta 2006 so se tu povečala gozdna območja. Tudi v tem oknu v preučevano časovnem zaporedju ni bilo zaznanih prodišč. Pozidana in vodna območja so se skozi čas zmanjševala. Vidne so tudi spremembe lege naselij; naselje je bilo sprva skoncentrirano na severovzhodu, kasneje pa se je pomaknilo na severozahod, vzdolž novejše severne cestne povezave. Izgradnja ceste je imela očitno velik vpliv na premik naselja. Preverjanje pokrovnosti tal je tudi pokazalo, da so nekdanje sadovnjake in vinograde prerasli gozdovi.

Slika 8: Spremembe v razmerjih tipov pokrovnosti tal skozi čas za poplavno ravnico reke Mure.

Glej angleški del prispevka.

V 1780-ih so v preučevanem oknu poplavne ravnice reke Mure prevladovala poljedelska zemljišča (slika 4). Sredi 19. stoletja so se poljedelska zemljišča razširila $\mathrm{v}$ rečni koridor in $\mathrm{v}$ gozd na severovzhodu. V 80. letih 19. stoletja je prišlo do dodatnega širjenja poljedelskih zemljišč, do manjšega širjenja pozidanih območij ter premika struge reke Mure. Največja sprememba se je zgodila v 1940-ih in je povezana s strugo reke Mure. To je najverjetneje posledical regulacije struge. Nadaljnjo zmanjšanje poljedelskega območja je potekalo v 70. letih 20. stoletja, ko je prišlo do širjenja naselij. Nekaj poljedelskih območij se je razvilo tudi znotraj rečnega koridorja. Rast pozidanih zemljišč in pogozdovanje sta bila leta 2009 poglavitna razloga za izgube poljedelskega območja.

V 80. letih 19. stoletja je prišlo do drastičnega upada površine gozdnih zemljišč, ki se je odtlej širil, predvsem na račun poljedelskih zemljišč. Povečanje površine gozda smo zabeležili v 40. letih in v 70 . letih 20. stoletja. Območja gozda so se še dodatno povečala tudi v letu 2009, najverjetneje zaradi izvedenih obcestnih nasadov.

Površina prodnatih rečnih bregov je nihala predvsem $\mathrm{v}$ odvisnosti od dinamike reke v posameznem obdobju. Spreminjanje Murine rečne struge v preučevanem obdobju je povzročilo, da je danes njena struga uravnana in da so se pojavili novi rečni rokavi. 
Terensko preverjanje je razkrilo le omejeno območje z naravnim obrečnim rastjem in obširna pogozdena območja na slabo izsušenih rečnih prodih. Človekovo motenje prsti je med drugim omogočilo širjenje invazivnih tujerodnih vrst.

Slika 9: Spremembe v razmerjih tipov pokrovnosti tal skozi čas za jugozahodno Goričko.

Glej angleški del prispevka.

Največja širitev poljedelskega območja na jugozahodu Goričkega iz 1880-ih se ujema z obširnim krčenjem gozdnih zemljišč. Tudi površina gozdnih območij se ujema z zmanjševanjem poljedelskih zemljišč. V tem oknu prevladuje gozd. Čeprav zemljevidi iz 80. let 19. stoletja prikazujejo samo jugovzhodni del območja, ugotavljamo, da je v tem obdobju prišlo do zmanjšanja površine gozda in obrečnega rastja na vzhodnem delu rečne struge. Zemljevid iz 70. let 20. stoletja pa kaže na ponovno širjenje gozda. Ostala gozdna zemljišča, ki so bila prikazuna na zemljevidu iz 70. let 20. stoletja, so še vedno ohranjena. V tem oknu ni bilo prodišč. Na vseh treh vojaških zemljevidih je mogoče opaziti stalno rast cestnih povezav in ostalih urbanih elementov. Kljub temu ostajata osrednji del prvotnega gozda in poznejše ponovno pogozdeno območje nenaseljen. Naselja so se najhitreje širila med leti 1970-ih in 2009. Zemljevid tega okna je edini primer, kjer rečni sistem, ki je pravilno kartiran na zemljevidu iz 1780-ih, ostaja statičen. Edina dokumentirana sprememba se pojavi na zemljevidu iz leta 2009, ko obrečno rastje zakrije vzhodni breg struge.

\section{Razprava}

Med analizo smo izluščili pomembne značilnosti posameznih geografskih oken. Interpretacijo dinamike pokrovnosti tal smo opravili z analizo zgodovinskih zemljevidov in z njo prikazali, kako so meje vplivale na izgled današnje pokrajine v Prekmurju.

\subsection{Jugovzhodno Goričko}

S kombinacijo metod je bilo mogoče ugotoviti, da jugovzhodno Goričko pooseblja značilnosti naravne/estetske pokrajine, ki ne odraža zgolj lepote nekega kraja ali razgleda, temveč poudarja kriterije, s pomočjo katerih je mogoče določiti dinamično strukturo nekega okolja na celosten in integriran način. Karta stabilnosti severovzhodnega Goričkega prikazuje značilnosti naravne/estetske pokrajine v posebni geografski kategoriji, ki jo opisujeta Williams in Patterson (1999: 144). Dobljeni rezultati stalnosti sprememb rabe tal se ujemajo s psihološko interpretacijo Kaplana in Kaplana (1989). Dolgotrajna stabilnost označuje mirno okolje - enega od udobij, ki jih ljudje cenijo in obenem pomeni enega od potencialnih pogojev za dojemanje lepote, kot jo opisujeta omenjena avtorja. Terensko preverjanje potrjuje naravno/estetske značilnosti preučevanih oken.

\section{2 Örség}

Politične odločitve lahko močno vplivajo na spremembe rabe tal, kar je razvidno iz karte stabilnosti (slika 3) in terenskih preverjanj. Družinske kmetije so bile kolektivizirane (Olas in Kert 1993), zato je danes mogoče zaznati opazne razlike v ruralnem bogastvu med Örségom in jugovzhodnim Goričkim, ki ju loči državna meja.

»Paradigma blaga « je termin, s katerim so ocenili kapaciteto naravnih virov za doseganje vedenjskih in gospodarskih ciljev (Williams in Patterson 1990). Predpostavke, ki se ustvarijo pri instrumentalnem pogledu na okoljsko vedenje, sledijo idejam, ki sta jih Saegert in Winkel (1990) definirala kot priložnostna strukturno/ciljno usmerjena paradigma znotraj okoljske psihologije. Ljudje so razumljeni kot racionalni načrtovalci, ki v sistemu priložnosti in omejitev vedno izberejo najboljšo možnost. Splošna značilnost gozda v Örségu je, da še ne dosega zrele faze, kar zopet kaže na procese zaraščanja kmetijskih zemljišč v času zaprtosti državne meje. Instrumentalna oziroma ciljno usmerjena paradigma omeji omeji okoljske vrednote le na tiste, ki temeljijo na gospodarskem modelu (Williams in Patterson 1996). Te vrednote so v komunističnem obdobju obvladovale okolje Örséga. Proizvodnja surovin in gospodarska učinkovitost sta tako nadvladovali čustvenemu poistovetenju s krajem in identiteti (Williams in Patterson 1996). 


\subsection{Poplavna ravnica reke Mure}

Zaščitena z globoko strugo in rečnim nasipom, ki omejujeta poplave, je Mura še danes geografska meja; četudi je rečni tok nekoliko uravnan. Reka vpliva na okolje in družbo. Mura je bila tisočletje naravna in politična meja med Prekmurjem in preostalim sedanjim slovenskim ozemljem, danes po njej teče politična meja s Hrvaško. Reka Mura je prevladujoč element v pokrajini in dejavnostih $\mathrm{v}$ tem oknu in ima kulturne/simbolične značilnosti. Na splošno je simboličen pogled na pokrajino čustveno bogatejši kot instrumentalen, saj čustva zbujajo občutek »biti« v okolju. Čeprav smo s kartiranjem stabilnosti natančno določili dinamiko sprememb rečne struge, premik med naravnim obrečnim rastjem in nasajenimi nasadi ni jasno prikazan. Drevesne vrste, kot sta navadna robinija in ameriški jesen, so bile v Prekmurju načrtno nasajene že med leti 1934 in 1938 (Potočnik 1939).

\subsection{Jugozahodno Goričko}

Prostorska identiteta jugozahodnega Goričkega ne pomeni le kontroliranih strug vodotokov in bogatega prepleta obdelanih polj, katerih poljedelska tradicija sega vse do rimske poselitve tega področja, temveč leži tudi v simbolnem pomenu cerkva, ki največkrat stojijo v središčih vaških skupnosti in niso izolirane na vrhovih gričev. Značilni koničasti zvoniki in kovani križi so pomemben del lokalne kulturne identitete. Dolgoročno stabilnost tega območja gre pripisati tudi tipu prsti in obilici gozdnih virov. Površina gozdnih zemljišč je danes po velikosti podobna površini gozda na Jožefinskem vojaškem zemljevidu. Gozd je izgubil veliko svoje nekdanje naravne dinamike zaradi gospodarskega izkoriščanja.

Pomen posameznih, ekspresivnih izrazov se tukaj lepo odseva v konceptu posameznikovega identificiranja z nekim krajem; ta se pojavi zato, ker so kraji prežeti z osebnimi, socialnimi in kulturnimi pomeni, v sklopu katerih se ustvari, ohranja in preobrazi neka identiteta (Williams 2002; Williams in Patterson 1996; Williams in sodelavci 1992).

\section{Sklep}

$\mathrm{Z}$ metodologijo, uporabljeno $\mathrm{v}$ tej raziskavi, smo predstavili uporaben pristop za analizo sprememb rabe tal za preučevana območja. Kartiranje stabilnosti je bilo uporabljeno že v številnih drugih raziskavah sprememb pokrovnosti tal in dinamike pokrajin (Skokanová in sodelavci 2009; Swetman 2007), vendar pa te raziskave niso uspele vzpostaviti povezave s spremembami pokrovnosti tal, interakcijami med ljudmi in kraji ter vplivi meja na te spremembe.

Trije kazalniki (podobnost, preobrat in raznolikost), ki jih je mogoče precej enostavno izračunati z GIS-i, so se izkazali kot uporabni prostorski kazalniki (Swetman 2007). Najbolj zahteven je bil izračun preobrata, vendar prav ta daje najbolj zanimive podatke o dinamiki pokrovnosti tal. Izračun preobrata ima to pomanjkljivost, da ga je treba subjektivno interpretirati z uporabo majhnega števila kartografskih podatkovnih baz. Posledično je lahko izračun preobrata za preučevana okna, kjer imamo manjše število kartografskih podatkov (okno Örség in jugozahodno Goričko), podvržen subjektivni interpretaciji. Število vnesenih podatkovnih baz je pomemben omejevalni dejavnik. Po našem mnenju je minimalno število vnesenih podatkovnih baz šest, da lahko z gotovostjo zaznamo vse spremembe v procesih. Čeprav uporaba zgodovinskih zemljevidov omogoča, da opravimo analizo dolgotrajnih sprememb v pokrajini, je takšna analiza odvisna od kakovosti zgodovinskih zemljevidov in njihove interpretacije. $V$ tej raziskavi nismo merili stopnje nezanesljivosti zemljevidov, ki smo jih uporabili. Na primer, na zemljevidih Örséga iz 1840-ih in 1880-ih se pojavijo razlike $\mathrm{v}$ označevanju cest in naselij, kar je lahko posledica razlik v natančnosti zemljevidov. Tudi prekrivanje rečnih strug je zelo slabo predvsem zaradi linearnosti rek, načinov kartiranja in slabega lociranja. Kljub temu pa so številni zemljevidi prikazovali pomembne značilnosti v pokrajini: oglat rečni ovinek v rečni strugi nad krajem Magyarszombatfa; oglat prehod iz mosta po reki navzgor od kraja Velemér in označen severni pritok. S terenskim preverjanjem, ki se je izkazal za esencialnega, smo preverili rezultate izpeljane iz serij zemljevidov (Ellis Burnet in Ribeiro 2010).

$S$ pomočjo slikovnega prikaza na zemljevidu, kartiranja stabilnosti in kasnejšega preverjanja podatkov na terenu (terenska okoljska ocena) smo uspeli dokazati, da je Prekmurje skozi stoletja ostalo relativno stabilno. Dejavnosti človeka v okolju se le neznatno, a kljub temu zaznavno, oddaljila tako od naravnih 
kot umetno ustvarjenih meja: te so reka Mura, politično določene meje, ki je z ograjevanjem, postavljanjem nadzornih stolpov in strogim vojaškim nadziranjem močno zaznamovalo pokrajino (Železna zavesa). Analiza podatkov niza zemljevidov se je izkazala za pomembno, najbolj uporabno pa je bilo kartiranje stabilnosti, ki omogoča jasen prikaz vpliva, ki ga imajo naravne in politične meje na spremembe pokrovnosti tal.

\section{Zahvala}

Ta članek je nastal v sklopu projekta TransEcoNet, ki se izvaja v okviru programa Srednja Evropa in ga sofinancira ERDF. Del raziskave je bil opravljen v sklopu raziskovalnega programa P4-0107: Gozdna biologija, ekologija in tehnologija, ki ga financira Javni raziskovalni zavod RS. Avtorji se zahvaljujemo Matiji Zornu, Katji Milost, Romini Rodela, Stanki Dešnik in Michaelu Givenu za njihovo pomoč in prispevek $\mathrm{k}$ temu članku. Zahvala gre tudi anonimnima recenzentoma za njune koristne nasvete pri branju prvotnega besedila.

\section{Literatura}

Glej angleški del prispevka. 